\title{
Effect of Marketing Factors on Brand Relationship Equity and Affects the Customers' Purchase Intention
}

\author{
Bahman Hajipour \\ Faculty of Economy and social science \\ Associate in management, Shahid Chamran University, Ahwaz, Iran \\ E-mail: Bhajipour@Gmail.com
}

\begin{abstract}
Belgheys Bavarsad
Assistant Professor in management, Faculty of Economy and social science

Shahid Chamran University, Ahwaz, Iran

E-mail: Bita40@yahoo.com
\end{abstract}

Seyede Elham Zarei (corresponding author)

M.S in marketing management, Faculty of Economy and social science

Shahid Chamran University, Ahwaz, Iran

Tel: 98-912-414-4775_E-mail: e21_zarei@yahoo.com

Received: Dec. 24, 2012 Accepted: January 8, 2013 Published: January 9, 2013

doi:10.5296/jmr.v5i1.2947

URL: http://dx.doi.org/10.5296/jmr.v5i1.2947

\begin{abstract}
Today, achieving the stable competitive advantage is one of the most important tools in the business world. To this aim, with creating and using the powerful brand equities,the firms have entered into different competitive fields. Also, in the marketing activities the relationship with customer is the main pivot and getting the customers' attraction is the priority of all the firms. On the other hand, with the advancement of the nutrition industry of the world, the relationship brand equity for the nutritional companies in order to attract more customers as well as seeking more income has been accentuated which is one of the main components of the firms' success. In this study, the marketing mix effect on the relationship brand equity and its effect on the customers' purchase intention of the two well-known brands of the dairy industry of Iran have been discussed. The sample of the study included 522 consumers in Iran. The data analysis has been done using LISREL 8.5 and SPSS 16.00
\end{abstract}


Software. The results indicate that two factors of advertisement and the target brands promotions of this industry have a significant effect on the perceived quality, while with increasing the price component of the perceived quality by customers have been decreased. On the other side, the perceived quality has also a significant effect on the brand equity. Finally, the results indicate that the relationship brand equity has a significant effect on the customers' purchase intention on these brands. At the end, some suggestions for improving the active companies' function in this industry as well as suggestions for the future studies have been provided.

Keywords: Brand, Relationship Brand Equity, Perceived Quality, Purchase Intention. 


\section{Introduction}

These days, in order to compete and achieve the success in the business world the companies need the efficient tools to carry out their goals. One of the most important competition tools in the business world for attracting, preserving, and increasing the consumers is having powerful brand equity. The brand equity is included as intangible and essential properties of any company which is acquired through the customers' attitudes and behavior.

Despite of the extent of the research which has been implemented on the field of the brand equity (Aaker, 1996; Keller, 1993; Erdem \& Swait, 2004; Tolba \& Hassan, 2009), the aspect of the brand equity has not specifically been at the center of attention so far. Also, most of the implemented researches in the industries like hotel industry and chain restaurants (Kim \& Kim, 2004), brand equities existed in TV industry and automobile (Pappu, 2005) and fuel industry (Tolba, 2011) have been carried out. Therefore, the current study investigates specifically this aspect of the customer based brand equity in the dairy industry. The results of this study can present appropriate information to the managers and people involved in this industry in Iran and also present the effective factors on the customers' purchase intention. Accordingly, the obtained results can view the future policies of the companies involved in this industry.

\section{Theoretical foundations and review of the literature}

\subsection{Brand equity}

The concept of the brand equity was created about 20 years ago as a basic concept in the marketing. The brand equity refers to the part of the product that is appertained to the brand. Form the managing viewpoint, Farquhar (1989) called the brand equity "an added value" which a brand grants to a product. Aaker (1991) called the brand equity as a set of properties and debts related to the brand.

Gil et al (2007) believe that the brand equity is a value added to the product by brand equity. Generally, the brand equity is the consumers' understanding of all advantage and superiority which a brand carries in comparison with other brands. The customer based brand equity (CBBE) has three aspects of knowledge equity, attitudinal equity, and relationship equity. In this study, by investigating the relationship equity aspect and some important marketing factors the customer's purchase intention behavior is investigated.

\subsubsection{Knowledge equity}

Knowledge equity is a part of the customer based brand equity which evaluates the customers' awareness of brand equity (including recognition and brand reminding) and also the amount of their familiarity with characteristics, concepts, and the functions of a brand. The knowledge equity measures the rate of the effectiveness of the messages conveyed to the customers about brand equity (Keller, 2003). 


\subsubsection{Attitudinal equity}

Attitudinal equity refers to the customers' attitudes about a specific brand equity. As Keller (2003) defined the customer's mental (attitudinal) criteria include "anything in the mind of the customer related to a brand equity (like thoughts, emotions, experiences, imaginations, perceptions, beliefs, and attitudes) and also include an extended spectrum of quantitative and qualitative criteria of the brand equity.” Lassar (1995) has identified the following structures of the customer based brand equity:

- $\quad$ Perceived quality: covers the brand functions.

- $\quad$ Perceived equity: covers desirability and financial affordance of the brand.

- $\quad$ Social image: (here is presented as prestige) covers the social aspects.

In addition, Percy and Rossiter (1992) state that the attitude toward the brand equity has two emotional and identified aspects. Their study has focused on the structural attitudinal equity effects for covering the emotional aspects and presenting a more comprehensive criterion.

\subsubsection{Relationship equity}

Relationship equity covers the perceived equity, the customer's satisfaction and the attitudinal loyalty to the brand. The relationship equity involves the aspects relevant to the connection between consumer and brand equity specified to them and investigates the effectiveness of the marketing activities on creating the relationship between brand equity and the targeted customers (Keller, 2003).

\subsection{Perceived quality}

Perceived quality is the customer's perception of the total quality of a product or a service in comparison with other alternatives (Aaker, 1991).

Jones, Hill, and Hiller (2001) state that there is a positive relationship between the perceived quality of the service with the intention of the further purchase, its recommendation and resistance against the better alternatives which is interpreted as the customer loyalty to the brand. Stafford \& Wells believes that the perceived quality is regarded mostly by customers' long-term attitude (Stafford \& Wells, 1998). The brand equity perceived quality is defined as the consumers' judgment about the total desirability of the brand (Rowley, 1998). Rowley believed that the perceived quality is not necessarily including the objective and real aspects of something, but is a kind of attitude which related to the customers' satisfaction and originates from the customer's expectations comparison with its function. Although there have been many definitions about the perceived quality, its conceptual definition is complicated and it has been called elusive (Cronin, Brady, \& Hult, 2000).

Brand equity or the perceived quality is tied by the customer, a perception which only shows the total quality and is not merely based on the customers' knowledge about its micro-characteristics. Total perceived quality may be different to some extent in variousindustries (Keller, 1993). High quality affects directly the purchase intention and loyalty and supports the price and more benefit. Also, it can be a base for extending the range 
of the brand equity (Aaker, 2000). In this study, the perceived quality is the customers' mental judgment about the function of a product (Zeithaml, 1988).

In addition, three other factors which are effective on the perceived quality factor are price, advertisements, and promotions.

Hypothesis 1: increasing the advertising expenditures has a positive and direct effect on the customers' perceived quality of the brand.

\subsection{Advertisement}

Advertisement is defined as any introduction and promulgation of ideas, goods, or services which an advertisement unit, individual, or institution implements and required expenditure (Kotler, 2001). The marketing researchers have found that advertisements are effective in brand equity’s quality increasing (Boulding \& Amna, 1994; Johnson, 1984).

The advertisements' expenditures indicate the amount of the investment of the firm or company in its own brand equity and the consumer holds a positive connection between the advertisements' expenditures and the quality of the brand equity. (Mailgram et al 10-25, 1986; Simon et al 28-52, 1993; Cobb-Walgren et al 25-41, 1995; Gil et al 91, 2007).

Hypothesis 2: the price of a brand product has a positive and direct effect on the customers' perceived quality of the products of that brand.

\subsection{Price}

Price is the amount of money or value which the consumers pay for getting the advantages of the possession or using goods or services (Kotler \& Armstrong, 2001, p.371). Pricing is a dynamic process. Companies establish the price structure in a way that covers all of their merchants, but this structure changes by passing the time. A company balances its pricing structure based on the consumers' characteristics and their conditions. Depending on the existed difference between consumers and different conditions use the different pricing balancing policies. When a company thinks to price changing it should consider the consumers and competitors' reaction.The consumers' reaction depend on their tension with the price will be different. The competitors' reaction is stereotypical or results from analyzing any condition. A company which possesses the price changing initiative should consider the ingredients' sellers reaction, selling promotioners, and the government. A company which noticesthe competitor's price changingshould discern this intention. Knowing the period of price changing and its effect on the company is necessary. In case of necessary quick reaction, the company should plan its reaction depending on the different changes which the competitors impose on their selling price (Kotler \& Armstrong, 2001, p.276).

Customers use the price as an index of the products or service quality. The expensive brands are assumed to be the brands with more quality than inexpensive ones in the customers' minds (Blattberg \& Winniewski, 1989). Yoo et al (2000) believe that a direct and significant relationship has not been identified between price, awareness, and the brand association. Both high and low price can associate some advantages in the customers' minds, and these two contribute to the customers' awareness of the brand. The price indicates the brand's quality. 
Generally, the powerful brands create a perception of high quality in the customers' minds and vice versa (Mailgram et al 11, 1986; Rao et al 352, 1989; Gil et al, 2007).

In this study, the perceived price by consumers is price which can be different from the real prices (Yoo, Danto \& Lee, 2000).

Hypothesis 3: the amount of the promotions expenditures in brand equity has a significant and inverse effect on the customers' perceived quality of the brand.

\subsection{Promotion}

sale promotions can be based on the on the price(price promotions) or non-price (Peattie \& Peattie, 1993) and includes actions such as the periodical purchase research, presenting the purchase cards or vouchers, awards, refunding the purchased goods, refund the money or these kinds (Gupta, 1988). In price promotions more advantage is going to be presented by decreasing the prices and usually is presented for a specific period time, location, and/or customers to stir up the target groups reactions against the marketing activities (Peattie \& Peattie, 1993). Price promotions are presented because of different reasons. The most important advantage that can be considered for the price promotions is that the customers' purchase process at the time of shopping can be affected by it (Alvarez \& Casielles, 2005). Sometimes by price promotions the companies sell their extra products in their storehouses. One of the other reasons for applying this approach is attracting new customers and more shares in the market. Another reason which can be assumed for this act is that it is expected that the customers who purchase some products with discount have more motivation to purchase other products of the company which do not have price promotions. Among other advantages of the price promotions there is a positive effect which it has in short term (Raju, Srinivasan \& Lal, 1990).

Increasing the promotions expenditures can decrease the perceived quality of a brand in the minds of the consumers (Suri et al, 2000; Jorgensen et al 2003).

Hypothesis 4: the perceived quality of the brand has a positive and direct effect on the relationship equity.

Hypothesis 5: the relationship equity has a positive and direct effect on the purchase intention of the brand by the consumers.

\subsection{Purchase intention}

According to Day (1969), the related criteria with customers' intention is more effective than with their behavior in finding what is in customers' minds, because it is possible due to having limitations promotion with the final and real purchase intention and this is not because of their own preferences. For testing the customers' behavior pattern and their real purchase behavior the purchase intention is used (Ajzen \& Fishbein, 1980, p.3). In different studies, the correlation of purchase intention and the real purchase behavior has been proved (Ajzen \& Fishbein, 1980; Oliver \& Bearden, 1985, p.4). 
In businesses like hotel business and tourism this correlation has been tested and proved. In a research by Armstrong, Morwitz and Kumar (2000) which has been implemented on four sample product four approaches which evaluate the purchase intention have been used. The findings indicate that using the approaches which determine the purchase intention are intended for predicting a better sale processes than former selling ones. Other findings were about the time when these four approaches of evaluating the customers' purchase intention come to an end, the sale prediction error reaches to the one third of prediction error of the time of former selling approaches. Some of these studies which promotion with the effective factors on the purchase intention are provided as following:

Grewal et al (1998) in investigating the department store's name, brand and price discounts' effects on the customers' evaluation and purchase intention concluded that the department store's name and the brand quality affects the perceived image of the department store. On the other hand, the price discounts and perceived quality of the brand has a significant effect on the perceived value. Now, the perceived value and the department store's image both have a positive effect on the purchase intention. The findings of the Chen and Change (2008) study in investigating the relationship of the brand equity and the brand preference with the airlines passengers' purchase intention indicate that there is a positive relationship between brand equity and also the brand preference with purchase intention. However, the cost of the airline changing has a balancing effect on this relationship.

Based on the discussed subjects the conceptual model of the research is show in Figure 1.

\section{Methodology}

This research is an applied one from the perspective of purpose and nature and a descriptive one based on the data collection, testing hypothesis, and conclusion. Since the data collection instrument is a combination of library and field study, the current study has been implemented as a survey descriptive one.

\section{Sample population}

The statistical population of the current study includes all of the consumers of the dairy products all over Iran which consume two brands of Kaleh and Damdaran. The number of sample is 522 consumers of Tehran province which is the most populated city and the capital city of Iran which have been selected via cluster sampling. For better population description and its clearer understanding the descriptive statistics has been applied. Table 1 illustrates the number and the frequency percentage of the relevant variables.

\section{Instrument}

For data collection, questionnaire has been used. The questionnaire contained 6 demographical questions and 20 other questions for measuring other variables. For reliability of the questionnaire Cronbach Alpha has been used. The sources of the questionnaires questions and the Cronbach Alpha's results are provided in table 2. Regarding this table, it is clear that the questionnaire has a favorite reliability.

\section{Model fitness and investigation of the hypotheses}


With respect to the figures 2, 3, and table 2 it is clear that the model has a good fitness and table 5 shows that hypotheses $1,3,4$, and 5 are confirmed and hypothesis 2 is rejected.

\subsection{Confirmation factor analysis}

Regarding the indices presented in table 3, it can be stated that the confirmation factor analysis of the model has a good fitness. On the other hand, the standardized factor loads indicate the high observed variable correlation and the investigated factor. According to figure 2, it is clear that the factor loads are all in an acceptable level, therefore the correlation between the observed variable and the investigated factor is observed. Also, the determining observed variables' coefficient is high which indicates the appropriate determination of the observed variable and the factor.

\section{Discussion and conclusion}

The hypothesis 1 states that increasing the advertisements expenditures has a positive and direct effect on the customers' perceived quality of the brand. This hypothesis with the t-value of 2.00 is confirmed with the certainty level of 95 percent because it is out of the range of $(-1.96,1.96)$. The results of this hypothesis are consistent with the results of Mailgram et al 1986, Simon et al 1993, Cobb-Walgren et al 1995, Gil et al, 2003.

Hypothesis 2 states that the price of the products of a brand has a positive and direct effect on the customers' perceived quality of that brand. This hypothesis with the t-value of -0.79 is rejected. This result is not consistent with the results of Blattberg and Winniewski 1989. The cause of this problem is that in Iran society there are many brands in the dairy industry, thus these brands' consumers have many options to choose and in case of the price increasing of the dairy product, depending on the amount of the customers' perceived value, their income and the price which are ready to pay for these products, some people prefer to change their consuming brand.

Hypothesis 3 states that the amount of the promotions expenditures in a brand equity has a significant and inverse effect on the customers' perceived quality of the brand.This hypothesis with the t-value of 4.54 is confirmed by the certainty level of 95 percent because it is out of the range of $(-1.96,1.96)$. This result is consistent with Suri et al (2000), Jorgensen et al (2003) results.

Hypothesis 4 states that the perceived quality of the brand has a positive and direct effect on the relationship equity. This hypothesis with the $t$ value of 4.91 is confirmed by the certainty level of 95 percent because it is out of the range of $(-1.96,1.96)$.

Hypothesis 5 states that the relationship equity has a positive and direct effect on the purchase intention of the brand by the consumers. This hypothesis with the t value of 5.33 is confirmed by the certainty level of 95 percent because it is out of the range of $(-1.96,1.96)$.

By investigating the obtained results it is clear that among the proposed marketing variables in the study which were effective on the customers' perceived quality, the promotion variable with the t-value of 4.54 is more effective than advertising and price variables and this variable is more important. Also, concerning the obtained results and confirming the intended 
hypotheses one can say that the relationship equity aspect is a very important aspect and effective on the customers' purchase intention.

\section{Suggestions}

As the results of this study indicate, considering the perceived quality aspect of brand is important. Therefore, the reasonable price of product and planning for informative, powerful and extensive advertisements as well as appropriate price promotions in order to increase the brand equity is an essential and important matter for the customers.

For the future studies following points are suggested to the researchers:

This model could be investigated for the domestic market conditions in Iran or other countries.

This study could be implemented in other cities and societies with different cultures.

The current study is applicable for other product and industries.

This study can be applied for foreign brands in domestic markets too.

\section{References}

Aaker, D. A. (1991). Managing brand equity: Capitalizing on the value of a brand name. New York: The free press.

Aaker, D. A. (1996). Mesearing brand equity across products and markets. California Management Review, 38(3), 102-120.http://dx.doi.org/10.2307/41165845

Aaker, David A., \& Joachimsthaler. Brand leadership, New York: The free press.

Ajzen, I., \& Fishbein, M. (1980). Understanding Attitudes and predicting Social Behavior. New Jersy: Prentice-Hall.

Alvarez, A.B, \& Casielles, R.V. (2005). Consumer evaluations of sales promotion: the effect on brand choice. European Journal of Marketing, 39(1), 54-70. http://dx.doi.org/10.1108/03090560510572016

Armstrong, J. S., Morwitz, V.G., \& Kumar, V. (2000). Sales forecasts for existing consumer products and services: Do purchase intentions contribute to accuracy? International Journal of Forecasting, 16, 383-397. http://dx.doi.org/10.1016/S0169-2070(00)00058-3

Blattberg, R.C., \& Winniewski, K.J. (1989). Price-induced paterns of competition. Marketing Science, 8(4), 291-309. http://dx.doi.org/10.1287/mksc.8.4.291

Boulding, W., \& Amna, K. (1994). A consumer-Slide experimental examination of signaling theory: Do consumers perceive warranties as signals of quality? Journal of Consumer Research, 20, 111-123. http://dx.doi.org/10.1086/209337

Chen, C. F., \& Change, Y. T. (2008). Airline brand equity, brand preference, and purchase intentions- The moderating effects of switching costs. Journal of Air Transport Management, 14(1), 40-42. http://dx.doi.org/10.1016/j.jairtraman.2007.11.003 
Cobb-Walgren KJ, Ruble CA, Donthu N. (1995). Brand equity, brand preference, and purchase intent, 24(3), 25-41.

Cronin, J.J., Brady, M.K., \& Hult, G.T.M. (2000). Assessing the effects of quality, value, and customer satisfaction on consumer behavior intentions in service environments. Journal of retailing, 76(2), 193-218. http://dx.doi.org/10.1016/S0022-4359(00)00028-2

Day, G.S. (1969). A two-dimensional concept of brand loyalty. Journal of Advertising Research, 9(3), 29-35.

Erdem, T., \& Swait, J. (2004). Brand credibility, brand consideration, and choice. Journal of Consumer Research, 31(1), 191-198.http://dx.doi.org/10.1086/383434

Farquhar,P.H. (1989). Managing brand equity. Marketing research, 1(3), 24-33.

Gil, R. BravoE. Fraj Andre's, \& E. Martı́nez Salinas. (2007). Family as a source of consumer-based brand equity. Journal of Product \& Brand Management, 16(3), 188-199. http://dx.doi.org/10.1108/10610420710751564

Grewal et al. (1998). The effect of store name,Brand name and price discounts on consumer's evaluations and purchase intentions. Journal of Retailing, 74(3), 231-352. http://dx.doi.org/10.1016/S0022-4359(99)80099-2

Gupta, S. (1988). Impact of sales promotion on when, what,and how much to buy. Journal of Marketing Research, 25, 342-355. http://dx.doi.org/10.2307/3172945

Johnson, T. (1984 ). The myth of declining brand loyalty. Journal of Advertising research, 24(1),9-17.

Jones, P., Hill, C.C., \& Hiller, D. (2001). Retailing: Revolution or evolution? Teaching Business \& Economics, 5(2), 32-38.

Jorgensen, S., Taboubi, S., \& Zaccour, G. (2003). Cooperative advertising in a marketing channel. Journal of ptimization Theory and Applications, 110(1), 145-158. http://dx.doi.org/10.1023/A:1017547630113

Keller, K. L. (1995). Conceptualizing, Measuring, and Managing brand equity. Journal of Marketing.

Keller, K.L. (2003). Strategic brand management: building, Mesearing and managing brand equity. ( $2^{\text {nd }}$ ed). Upper Saddle River: NJ: Prentice-Hall.

Keller, K.L., \& Aaker, D.A. (1992). The effects of sequential introduction of brand extensions. Journal of Marketing Research. 29(1),35. http://dx.doi.org/10.2307/3172491

Kim, H., \& W.G. Kim. (2004). Measuring customer based restaurant brand equity-Investigating the relationship between brand equity and firm's performance. Cornell Hotel and Restaurant Administration Quarterly, 45(2), 115-131. http://dx.doi.org/10.1177/0010880404264507 
Kotler, P. (2001). A framework for marketing management. Upper Saddle River, New Jersey: Prentice-Hall.

Kotler, P., \& Armstrong, G. (2001). Principles of Marketing. ( $9^{\text {nd }}$ ed).New Jersey: Prentice Hall.

Lasser, W., Mitta, B., \& Sharma, A. (1995). Measuring customer-based brand equity. Journal of Customer Marketing, 12(4), 11-19. http://dx.doi.org/10.1108/07363769510095270

Milgrom, P., \& Roberts, J. (1986). Price and advertising as signals of product quality. Journal of Political Economy, 55, 10-25.

Oliver, R.L., \& Bearden, W.O. (1985). Crossover effects in the theory of reasoned action: a moderating influence attempt. Journal of Consumer Research, 12(3), 324-340. http://dx.doi.org/10.1086/208519

Pappu, R., Quester, PG., \& Cooksey, R.W. (2005). Consumer-based brand equity: Improving the measurement-empirical evidence. The Journal of Product and Brand Management, 14(2), 143-154. http://dx.doi.org/10.1108/10610420510601012

Peattie, K., \& Peattie, S. (1993). Sales Promotion-Playing to win? Journal of Marketing Management, 9, 256-269.http://dx.doi.org/10.1080/0267257X.1993.9964237

Percy, L., \& Rossiter, J. (1992). A Model of Brand Awareness and Brand Attitude Advertising Strategies. Psychology \& Marketing, 9(4), 263-274. http://dx.doi.org/10.1002/mar.4220090402

Putrevu, S., \& Lord, K.R. (1992). Comparative an non-comparative advertising: attitudinal effects under cognitive and affective involvement conditions. Journal of Avertising, 23, 77-90.

Raju, J.S., Srinivasan, V., \& Lal, R. (1990). The effect of brand loyalty on competitive price promotional strategies. Management Science, 36, 276-305. http://dx.doi.org/10.1287/mnsc.36.3.276

Rao, A.R., \& Monroe, K.B. (1989). "The effect of price, brand name, and store name on buyers' perceptions of product quality: an integrative review”. Journal of Marketing Research,26, 351-357. http://dx.doi.org/10.2307/3172907

Rowley, J. (1998). Quality measurement in the public sector: some perspectives from the service quality literature. Total Quality Management, 9(2/3), 321-333. http://dx.doi.org/10.1080/0954412989171

Schiffman, L.G., \& Kanuk, L.L. (2000). Consumer Behavior. New Jersy: Prentice Hall.206.

Simon, carol j., \& Mary w. sullivan. (1993). the measurement and Dererminants of brand equity a financial. marketing science,12, 28-53. http://dx.doi.org/10.1287/mksc.12.1.28 
Stafford. M., Stafford, T., \& Wells, B. (1998). Determinants of service quality and satisfaction in the auto casualty claims process. The Journal of services Marketing,12(6), 426-440. http://dx.doi.org/10.1108/08876049810242687

Suri, R., Manchada, R.V., \& Kohli, C.S. (2000). "Brand evaluations: a comparison of fixed price and discounted price offers”. Journal of Product \& Brand Management,9(3), 193-206. http://dx.doi.org/10.1108/10610420010332458

Sweeney, J.C., \& Soutar, G.N. (2001). Consumer perceived value: the development of a multiple item scale.Journal of Retailing, 77, 203-220. http://dx.doi.org/10.1016/S0022-4359(01)00041-0

Tolba, A.H., \& S.S. Hassan. (2009). Linking Customer based brand equity with brand market performance:A managerial approach. Brand Manage, 18(5), 356-366. http://dx.doi.org/10.1108/10610420910981837

Tolba, Ahmad. H. (2011). The Impact Of Distribution Intensity On Brand Preference and Brand Loyalty. International Journal Of Marketing, 3(3), 56-66.

Tsiros, M., \& Mittal, V. (2000). Regret: a model of its antecedents and consequences in consumer decision making. Journal of consumer Research, 26, March, 401-17. http://dx.doi.org/10.1086/209571

Yoo, B., Donthu, N., \& Lee, S. (2000). An examination of selected marketing mix elements and brand equity. Journal of the Academy of Marketing Science, 28(2), 195-211. http://dx.doi.org/10.1177/0092070300282002

Zeithaml, V. A. (1988). Consumer perception of price,quality, and value: A Means-End Model and synthesis of evidence. Journal of Marketing, 52(3) 2-22. http://dx.doi.org/10.2307/1251446 


\section{Appendixes}

Table 1. Descriptive Statistics

\begin{tabular}{|c|c|c|c|}
\hline \multicolumn{2}{|l|}{ Variable } & \multirow{2}{*}{$\begin{array}{l}\text { percent } \\
52.7\end{array}$} & \multirow{2}{*}{$\begin{array}{l}\text { Frequency } \\
275\end{array}$} \\
\hline Gender & Woman & & \\
\hline & Man & 47.3 & 247 \\
\hline \multirow[t]{5}{*}{ Age } & Less than 30 years & 22.8 & 119 \\
\hline & Between 30-40 years & 40.4 & 211 \\
\hline & Between 40-50 years & 22.6 & 118 \\
\hline & Between 50-60 years & 9.8 & 51 \\
\hline & More than 60 year & 4.4 & 23 \\
\hline \multirow[t]{3}{*}{ Education } & Diploma & 37.5 & 196 \\
\hline & Bachelor & 42.9 & 224 \\
\hline & Master's degree or higher & 19.6 & 102 \\
\hline \multirow[t]{2}{*}{ Marreige } & Single & 28.5 & 149 \\
\hline & Marreid & 71.5 & 373 \\
\hline \multirow[t]{6}{*}{ Job } & Employer & 38.3 & 200 \\
\hline & Householder & 10 & 52 \\
\hline & Self-employment & 22.6 & 118 \\
\hline & Laborer & 9.2 & 48 \\
\hline & Student & 8 & 42 \\
\hline & Other Jobs & 11.9 & 62 \\
\hline \multirow[t]{5}{*}{ Income } & Less than 400,000 & 15.9 & 83 \\
\hline & Between 400,000-600,000 & 17.8 & 93 \\
\hline & Between 600,000-1,000,000 & 39.7 & 207 \\
\hline & Between 1,000,000-2,000,000 & 17.3 & 90 \\
\hline & More than 2,000,000 & 9.4 & 49 \\
\hline \multicolumn{2}{|l|}{ Total } & 100 & 522 \\
\hline
\end{tabular}

Table 2. Cronbach Alpha

\begin{tabular}{|l|l|l|l|}
\hline \multicolumn{1}{|r|}{ Variable } & Source & Cronbach Alpha & Number of question \\
\hline Perceived Quality (P.QU) & Keller \& Aacker 1992 & 0.693 & 2 \\
\hline Brand Relationship Equity (R.E) & $\begin{array}{l}\text { Sweeney \& Soutar 2001, } \\
\text { Tsiros \& Mittal 2000, Yoo et al } \\
2000\end{array}$ & 0.808 & 7 \\
\hline Advertising & Gil et al 2007 & 0.822 & 3 \\
\hline Price & Gil et al 2007 & 0.733 & 2 \\
\hline Promotion & Gil et al 2007 & 0.659 & 3 \\
\hline Purchase Intention & Putrevu \& Lord 1992 & 0.809 & 3 \\
\hline Total questionnaire & & 0.839 & 20 \\
\hline
\end{tabular}




\section{Macrothink}

Journal of Management Research

ISSN 1941-899X

2013, Vol. 5, No. 1

Table 3. Confirmatory factor analysis

\begin{tabular}{|l|l|l|l|l|l|l|l|l|l|}
\hline p-Value & Df & Chi-Square & RMSEA & RFI & IFI & NNFI & NFI & CFI & GFI \\
\hline 0.000 & 155 & 410.40 & 0.056 & 0.89 & 0.93 & 0.91 & 0.90 & 0.93 & 0.89 \\
\hline
\end{tabular}

Table 4. model reliability

\begin{tabular}{|l|l|l|l|l|l|l|l|l|l|}
\hline $\mathrm{p}$-Value & Df & Chi-Square & RMSEA & RFI & IFI & NNFI & NFI & CFI & GFI \\
\hline 0.000 & 162 & 618.12 & 0.074 & 0.87 & 0.91 & 0.90 & 0.89 & 0.91 & 0.86 \\
\hline
\end{tabular}

Table 5. rejection and confirming of the hypothesis

\begin{tabular}{|l|l|l|l|l|}
\hline Hypothesis & Variable & t-value & $\begin{array}{l}\text { Standardized } \\
\text { coefficients }\end{array}$ & Result \\
\hline H1 & advertising expenditures on customers' perceived quality & 2.00 & 0.12 & Support \\
\hline H2 & Price on customers' perceived quality & -0.79 & -0.05 & $\begin{array}{l}\text { Not } \\
\text { Support }\end{array}$ \\
\hline H3 & promotions expenditures on customers' perceived quality & 4.54 & 0.29 & Support \\
\hline H4 & perceived quality on relationship equity & 4.91 & 0.21 & Support \\
\hline H5 & relationship equity on purchase intention & 9.39 & 0.52 & Support \\
\hline
\end{tabular}

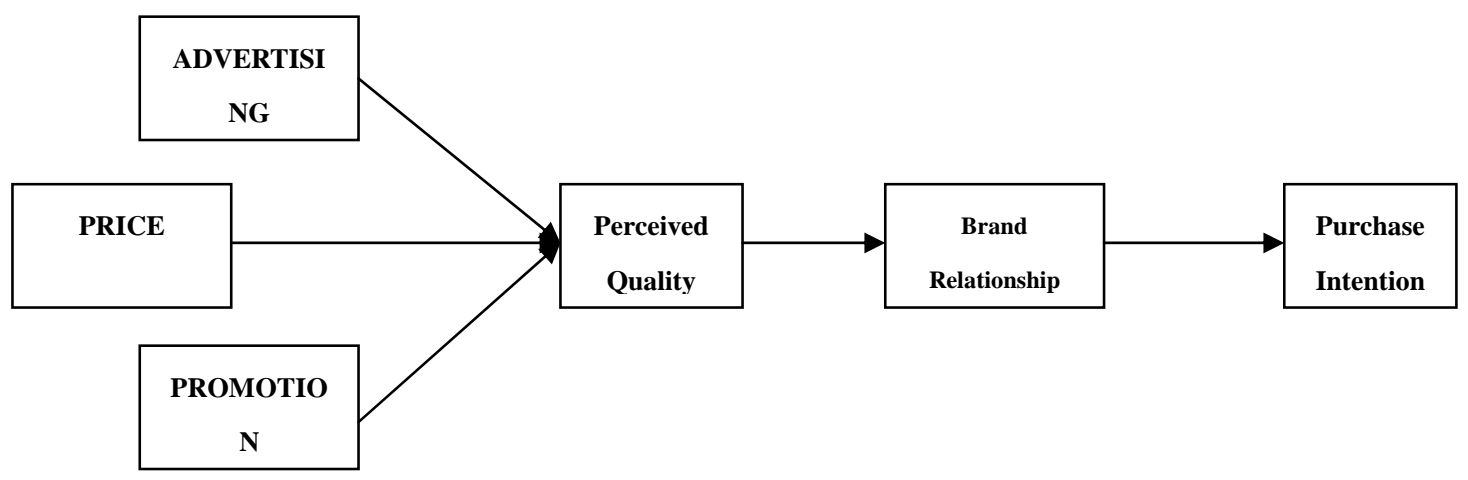

Figure 1. Conceptual Framework 


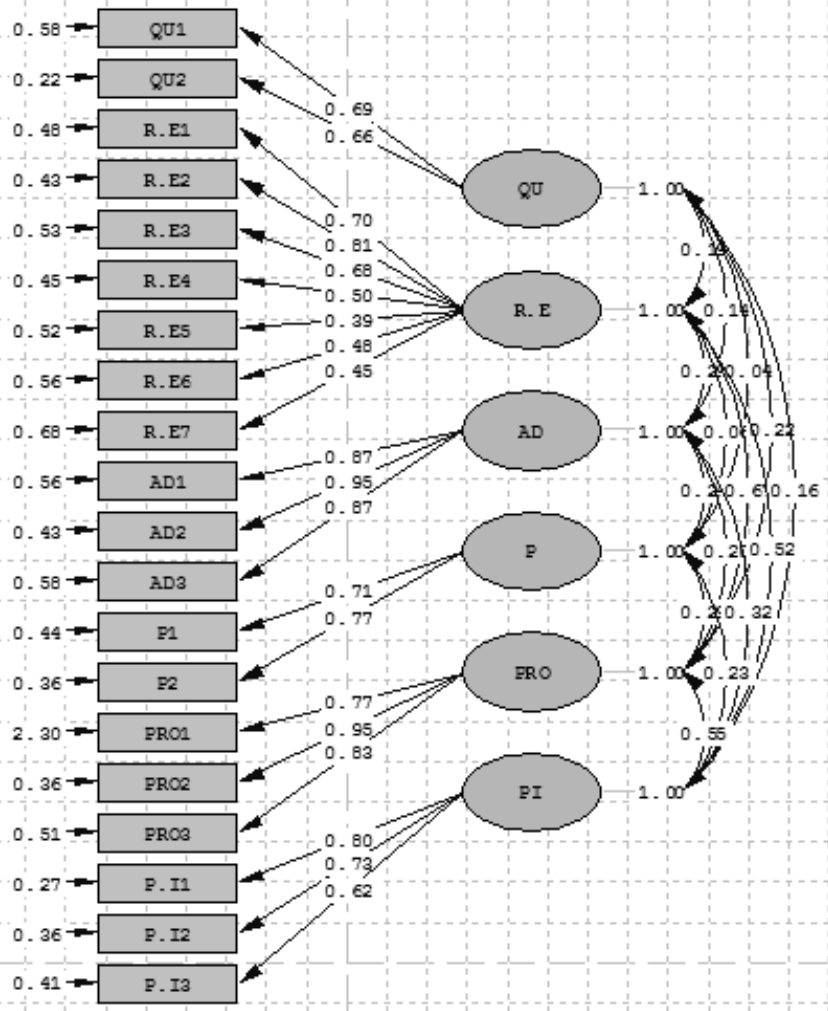

Chi-Square $=410.40, \mathrm{df}=155, \mathrm{P}-\mathrm{value}=0.00000, \mathrm{RMSEA}=0.056$

Figure 2. Confirmatory factor analysis

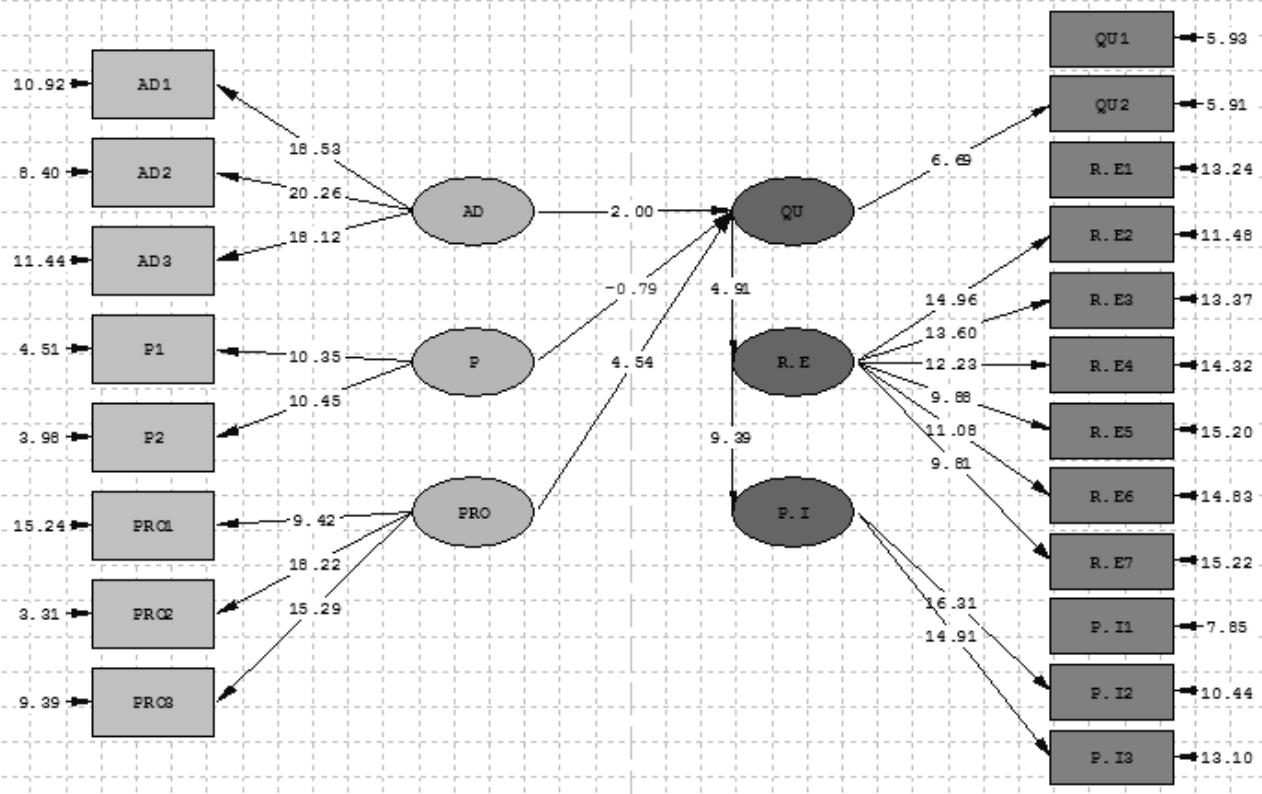

Chi-Square $=618.12, \quad$ df $=162, \mathrm{P}$-value $=0.00000, \quad \mathrm{RMSEA}=0.074$

Figure 3. Statistical models in T-value 


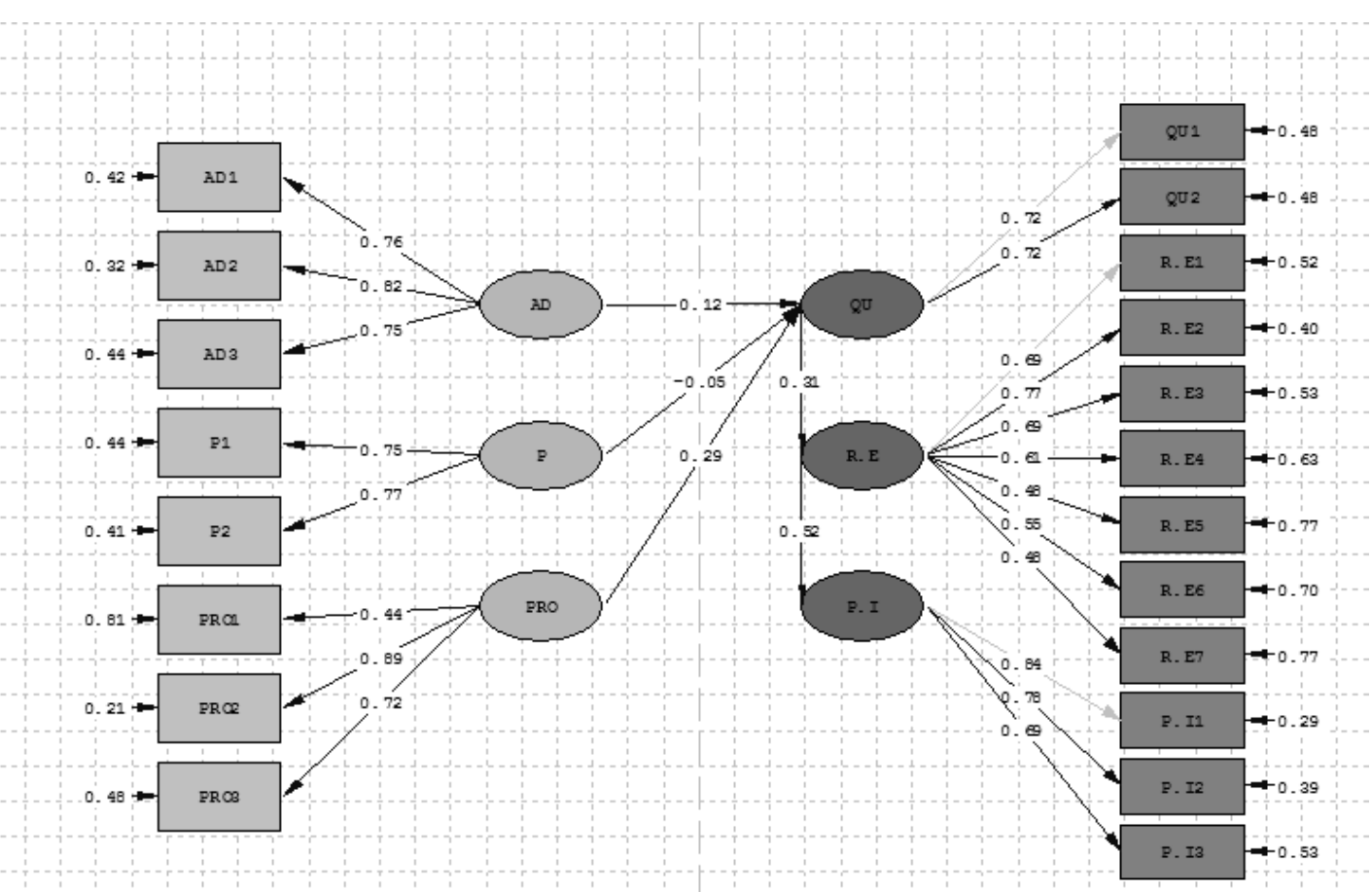

Chi-Square $=618.12, \mathrm{df}=162, \mathrm{P}$-value $=0.00000, \mathrm{RMSEA}=0.074$

Figure 4. Statistical models in Standardized solution 